\title{
Leadership Styles and Competence among Generation Z Emirati Nursing Students
}

\author{
Nabeel Al Amiri \\ Tawam Hospital, Al Ain, UAE \\ Fares Daradkeh and Amira Al Al Kaabi \\ Fatima College of Health Sciences, Al Ain, UAE
}

\begin{abstract}
Presently, Leadership is identified as one of the most critical factors that drive the UAE economic development, growth and innovation. On the other hand, nursing is a profession that has a vital role in maintaining country health well-being and its economy. In this study, the authors used a descriptive, quantitative methodology to study leadership practices and styles of Generation Z (born between 1995 and 1999) Emirati nursing students and explored the impact of those practices and styles on their competence, and performance and their potential to take over the leading position shortly. It was found that the students practice transformational, democratic, and servant leadership more frequently than the laissez-faire, transactional and the autocratic leadership and those styles were highly correlated to student's competence.
\end{abstract}

Keywords: Leadership; Leadership styles; Nursing Students; Generation Z; UAE.

\section{Introduction}

Leadership is essential in driving changes in human beings lives. In the fast revision of history, we quickly see that many people were recognized as leaders in one or more aspects of life. Those people have special attention of history as a result of their influence on people and their efforts to make changes in different aspects of life such as peace, war, science, technology, arts, laws, economy, business, and other fields. Good examples of those leaders are Hammurabi, Jesus, Mohammed, Alexander the Great, Edison, Gandhi, Mandela, Mother Teresa, and other thousands of leaders.

Leadership was not limited to those who made significant changes in human life; it also included a vast number of leaders who had influences on smaller groups of people in respect to social, military, business, religious, and other fields. All those leaders who succeeded in influencing people had specific 
qualities and followed specific manners (styles) to reach their goals. In early centuries, leaders adopted those styles by following the rule of thumb and having inherited leadership characteristics.

In the 20th and 21stcenturies, researchers studied leadership in depth and founded a solid basis for leadership as an art. According to Rost (1993), the average of books published on leadership is six books per year in1980-1983, and the number grew to twenty-three in 1989. About the numbers of leadership articles published in popular magazines and newspapers, no other specialized subject in the behavioural or social sciences could have a similar number of works that were given to the leadership in the 1980s (Rost, 1993). Later in 2015, the numbers of works have been published with the word "leadership" in the title reached nearly 1,246 paperback books (Iarocci, 2015). Vincent Lombardi (Famous Quotes by Vince Lombardi, n.d.), a great football coach (1913-1970) said "leaders are not born they are made just like anything else, through hard work. And that's the price we will have to pay to achieve that goal or any goal."

Many leadership theories such as the behavioural leadership theories support Lombardi quote. The Behavioural leadership theories assume leadership and leadership skills can be developed. Therefore, business and education leaders based on the new leadership theories focus on offering leadership programs and training to those who have the potential to lead. The Art of Leadership has a positive impact on people success in their business. It raises their confidence and skills to lead and manage their selves and others.

Although nursing is identified internationally as a profession that has a vital role in maintaining people health wellbeing and country's sustainable economies, UAE depended on non-Emirati nurses to cover the country needs for nurses for an extended period starting from the early 1960s (El Haddad, 2006). According to El Haddad (2006), the number of Emirati nurses who were in service in 2006 was around 150 nurses. She justified the low number of nurses as a result of many factors that included the low status of nursing in the UAE, the lack of resources, the affluent lifestyle of UAE nationals, as well as cultural and religious reasons. Therefore, the need to nationalize the nursing workforce in the UAE was identified as essential.

In the last 10 years, the UAE government supported nursing education through implementing many strategies such as establishing a well-equipped college of nurses, i.e., college of nursing at Sharjah University, Ras al-Khaimah (RAK) Medical \& Health Science University, Gulf Medical University and the four campuses of Fatima College of Health Sciences. Along with, they supported national nursing students by providing cost-free education. Furthermore, The Emirates Nursing Association (ENA), which established in 2001, has thankful initiatives to boost government efforts and improve nursing image among Emiratis.

In addition to technical competence, Emirati nursing students who were born between 1995 and 1999 (Generation Z) and are now on the seat of learning are expected to have leadership skills, as they will take over the leading nursing 
position shortly. In this paper, we will explore the leadership practices and styles among Generation Z Emirati nursing students at the four campuses of Fatima College of Health Sciences in Abu Dhabi, Al Ain, The Western Region, and Ajman. Furthermore, we will explore the impact of those practices and styles on their competence, performance, and their potential to lead.

\section{Literature Review}

\subsection{Leadership Styles}

In the last 200 years, scholars have proposed many leadership theories that explore the concept of leadership. Those theories include the Great Man theory (Carlyle et al., 2013, p. 21) which stated that those great leaders had qualities that enabled them to have a decisive historical impact; the charismatic leadership theory (Weber, 1978, p. 215) proposed charismatic leader as a leader who has exceptional sanctity, heroism, or exemplary character.

Furthermore, Lewin, Lippitt, \& White (1939) came up with a behavioural leadership theory that introduced three leader behaviour styles; autocratic (control), democratic (participation), and Laissez-faire (avoidance); theory $\mathrm{X}$ that describe manager's styles of coercion and control to manage those who are assumed to have an inherent dislike of work and theory $Y$ that describe manager's styles of participative and motivation to manage those who are assumed to seek responsibility by nature(McGregor, 1957); the Managerial Grid proposed that team management has a high concern for both employees and production (Blake and Mouton, 1964 as cited in Mind Tools, 2016); the servant leadership theory proposed that the leadership starts first with the desire to serve instead of the desire to lead (Greenleaf,1970 (as cited by Smith, 2005); the situational leadership theory proposed the using of telling, selling, participating, or delegating leadership style according to the level of followers maturity (Blanchard and Hersey, 1969); the transformational leadership that described the transformational leader as those who have a vision, develop culture, values, and teamwork, and elevate people from lower to higher levels of needs (Burns, 1978 (as cited by Fairholm, 2001); the Transactional or Managerial leadership theory that spoke about leaders who exercise the authority of office under formal legality, obey only the law, obligate others, follow the principle of hierarchy and recognize those who perform well, or threat those who have poor performance (Weber, 1947; Bass, 1990).

More theories including the distributed leadership theory that described interactions among multiple leaders from different level with or without formal positions rather than individual leader's practices (Spillane, 2005); authentic leadership that is drawn from organizational context, which leads to greater selfawareness and positive behaviours and self-development leadership (Luthans and Avolio (as cited in Walumbwa, Avolio, Gardner, Wernsing, \& Peterson, 2008); and the ethical theory that introduced leaders as a moral person with individual traits such as honesty, integrity, and trustworthiness, a moral manager such as doing the right thing, concern for people, and ethical decision making characteristics (Treviño et al., 2000). 
Lewin (1939) carried out an experiment on school to compare differences in behaviour that produced by each of the three leadership styles particularly democratic, autocratic, and lasses-fair. According to Lewin's experiment, boys were more aggressive under autocratic style, motivated and more creative under the democratic style, and less effective under the laissez-faire leadership.

Bass and Avolio (2002) have developed the Multifactor Leadership Questionnaire (MLQ) - form 6S which measures leadership on three styles that include transformational, transactional, and laissez- fair styles. Based on the (MLQ) - form 6S, the transformational leadership has four factors including idealized influence (Charisma), inspirational motivation, intellectual stimulation, and individual consideration. According to Felfe and Schyns (2002), the idealized influence is the ability of leaders to exert influence by serving as a role model, demonstrating both high commitment and high moral standards; the inspirational motivation is the ability of leaders to offer a convincing vision and an attractive goal to his followers and the degree to which the leader helps them to feel that their work is significant; the intellectual stimulation is the degree to which the leader encourages others to be creative and nurture people to question their own values and beliefs of the organization; and the individual consideration is the leadership ability to takes on the role of a coach or mentor and show interest in others' well- being.

According to Bass and Avolio (2002) survey, the transactional leadership has two factors including contingent reward and active management by exception. The contingent reward is the degree to which the leader tells others about their tasks, responsibilities, and expectations to be rewarded and the active management by exception is assuring that subordinates behave correctly and takes corrective actions when mistakes happen. The lasses-fair leader is avoidant and has little effect on his followers, and he usually let them do things in their own ways (Felfe and Schyns, 2002).

The servant leadership style focuses on followers rather than the organization. According to Paterson (2003), the servant leader leads and serves with 1) agapao love, i.e., having great love for the followers ; 2) acts with humility, i.e. avoiding over estimation of follower's merits; 3) altruistic, i.e., seeking what is best for followers rather than for the leader himself; 4) visionary for the followers, i.e., focusing on followers future state; 5) trusting, i.e., believing followers can accomplish goals; 6) serving i.e., primary function is based on follower's interests rather than leader's interests; and 7) empowers followers, i.e., giving freedom to followers to proceed toward their goals. Spears (2010) said businesses and notfor-profit organizations are shifting away from traditional autocratic and hierarchical models toward servant leadership. He identified a set of ten critical characteristics of the servant leadership that listening, empathy, healing, awareness, persuasion, conceptualization, foresight, stewardship, commitment to the growth of People, and building Community. In reference to a study in small businesses, it was concluded that the follower's perception of being empowered is necessary for the servant leader's empowering behaviours to be 
effective. Therefore, perceptions of empowerment may be enhanced by encouraging servant leadership behaviours through training or learning activities that aid leaders in becoming servant leaders (Van Winkle, Allen, DeVore, and Winston, 2014).

Kouzes \& Posner (2012, pp. 14-25) identified five practices of extraordinary leaders. These practices are modelling the Way, inspiring a shared vision, challenging the process, enabling others to act, and encouraging the Heart. They argued that leadership is a set of skills that can be learned, and acquired. According to Kouzes and Posner (2012, pp. 14-25), modelling the way is how confident the leader about his own guiding principles and affirming the shared values of the group and setting the example by aligning actions with shared values; inspiring a shared vision is the envision the future by imagining exciting and ennobling possibilities and sharing it with others; challenging the process is searching for opportunities and innovative ways to improve; enabling others to act is building trust, facilitating relationships, increasing self-determination and developing competence; and encouraging the heart is recognizing contributions, and showing appreciation for individual excellence.

Earlier, Posner (2004) developed The Student Leadership Practices Inventory (Student LPI) as one of the few leadership development instruments targeted college students. The instrument consisted of 8 elements that based on the eight leadership skills that mentioned above. In one study, Nanjundeswaraswamy and Swamy (2014) have summarized and analysed more than 40 pieces of literature of leadership styles and its effect on different components of quality of work life. They concluded that leadership style affects organizational culture by supporting competitiveness and innovation, which in turn influence organizational performance. In another review Khan et al., (2015) found that a combination of both the features of Transformational and Transactional Leadership in the first place and the style of Transactional Leadership in second place as the most influential styles of leadership among project's managers.

Furthermore, Dalluay and Jalagat (2016) found that manager's leadership style with respect to open communication, employee participation and cooperation with another department in achieving corporate goals promotes employee job satisfaction and performance. More, they found the participative (democratic) leadership style had the most substantial impact of the three common styles, autocratic, democratic, and lasses-fair, while laissez-faire had the lowest correlation. Similarly, a study of employees' job satisfaction in polish small and medium companies appreciated the role of democratic leadership on the highest employee's satisfaction when they were involved in strategic and operational plans in their company (Dyczkowska and Dyczkowski, 2018). Chua, Abdul Basit, and Hassan (2018) identified that the autocratic and democratic leadership style have significant positive or negative impact on employee's performance, while the Laissez Faire leadership style has a significant negative impact on employee performance. 


\subsection{Generation Z}

The theory of generations was, initially, proposed, in 1928 by the German socialist Karl Mannheim. According to Mannheim (1928), the generation is a social phenomenon that represents an age-related group who shared a particular kind of identity of place and time (described as "location"), and embedded in a historical-social process. This age-related group is determined by certain patterns of experience and thought that transit from one generation to another. Since Mannheim time until today, several generations were identified that are: 1) traditionalists or silent Generation (born before1945), 2) the baby boomers (born 1946 - 1964), 3) generation $X$ (born 1965-1980), 3) the millennials or generation $Y$ (born 1981- 1995), and 5) generation $Z$ (born after 1995) (The Pew Research Centre, 2019).

In today business world, the well-known fact is that most of the workers are millennials (born between 1980 to1995). Millennials (Buckley, Viechnicki, and Barua, 2015, p. 2) have recently exceeded the other generations to become the largest share of the US labour market. More, they are now occupying a growing number of senior positions. Another important fact is that generation $\mathrm{Z}$ is about to enter into the global work market and is expected to take a leadership role in the near future. Generation $\mathrm{Z}$ as widely defined is born in 1995-1999 and raised with the social web, and the digital technology revolution.

According to Tulgan (2013), Generation Z is expected to reach 30 million by 2019in the North American workforce. Therefore, Generation Z would represent the most significant generational shift the workplace has ever seen. Tulgan (2013) expected that Generation Z would present substantial challenges to work leaders as they have been shaped by nearly a decade of war and economic uncertainty and the contrast in their attitudes and behaviours is vivid. Iorgulescu (2016) identified the perception of a sample of Romanian Generation $\mathrm{Z}$ of the ideal workplace as they prefer to work in groups, and in open spaces offices. Also, the study confirmed that Generation $Z$ needs constant development, mentoring, and security. In another study, Ozkana and Solmazb (2015) more than three-quarters of Generation Z like to work with technology to accomplish their goals, state a strong preference for being hands-on with projects, select a corporate office space as their top work environment. Furthermore, Generation $\mathrm{Z}$ has strong desire for managers to listen to their ideas and value their opinions, for the people whom they work with to enable their best work, and for managers to allow them to work independently. On the other hand, the study showed that only one-quarter of Generation Z has a preference for a traditional office, co-working space that operates independently of the employer, and home office.

In respect to college education, the majority of Generation $\mathrm{Z}$ believes that colleges should allow students to design their own course of study or major, teach students about entrepreneurship, and the benefits of college outweigh the costs. More, they are confident in the importance of higher education to achieve their goals. Regarding technology and Cyber Safety, the majority do not prefer to interact with their friends via social media than in person (Northeastern 
University 4th Annual Innovation Poll, 2014). According to Singh and Dangmei (2016) review, Generations $Z$ seems to have different requirements and motivating factors that will affect the work as soon as they enter work organizations. Thus, it is crucial for organizations to discover how to establish a corporate culture and workplace to hunt top talents from the Generation Z, which in turn will sustain the organizational growth.

\subsection{Leadership Development and Competence}

Although changes exist across generation in the nature of effective leadership in response to the prevailing modern context, Ahn and Ettner ( 2014) in one comparison study on executive leaders from different sectors including business, military, religious, political, academia, judicial and medicine vs. earlycareer oriented MBA students found that there are some traits include sound judgment, leadership by example, decision-making, justice (fairness), humility and sense of urgency are similar in the view of both the MBAs and the executives. While other values include integrity and trust are viewed differently by executives and MBAs

On the other hand, Kaiser and DeVries (2000) concluded that organization's need for leadership remain constant during the time of unprecedented change that is due to rapid technological innovation, increasingly global market competition, growing demographic diversity in the labour pool, and other factors. In the recent years, leadership training is considered vital for professional development in most of the organizations. Unfortunately, according to the Global Human Capital Trends survey (Hagel, Wong, Benko, Erickson, 2014), most of the respondents including executives reported that they have "weak" capabilities in providing leadership programs for younger, older, and multi-generation workforces. Thus, such training and education are currently provided by many universities and educations institutes. Those institutes have provided either short courses or full MBA programs to produce leaders in business and other fields.

According to Bouvard (2013), the dean and director of Grenoble Graduate School of Business, business schools teach managers how to be team players rather than captains. Therefore, business schools need to provide a learning environment that will enable participants to acquire the technical knowledge necessary to run a business efficiently and stop promising them that they will all become the leaders of tomorrow as in any one company there can be only one leader. According to Rooke and Torbert (2005), what differentiates leaders is their internal "action logic" that is how they interpret their surroundings and react when their power or safety is challenged. Rooke and Torbert (2005) found that the seven action logics are distributed in the sample as opportunists $(5 \%)$, diplomat $(12 \%)$, experts $(38 \%)$, achievers $(30 \%)$, individualist $(10 \%)$, strategists $(4 \%)$, and alchemist $(1 \%)$. Also, they stated that leaders could transform from one action logic to another. For example, they documented a number of leaders who succeeded in transforming themselves from experts into achievers, from achievers into individualists, and from individualists into strategists 
Based on Giles (2016), the most 10 essential leadership competencies needed for effective leadership that are demonstrating strong ethics, clear communication of expectations, providing goals and objectives, distribution of power, flexibility to change opinion, open to new ideas and approaches, providing safety for trial and error, commit to ongoing training, and creating a feeling of succeeding and failing together as a pack.

In addition, leadership effectiveness was described as one of the leadership skills (fielder, 1964) that include possessing strong position power and selecting the best leadership style that matches the situation and followers. For example, Hill (1969) concluded that a supervisor dealing with professional people who perform unstructured tasks should adopt a democratic rather than an authoritarian leadership style. More, Doyle (2017) added analytical skills as one of the leadership skills which include collecting and analysing information, solving problems, and making a decision. On another hand, self-awareness, as described by Goleman, Boyatzis, and McKee (2013), is the most essential competent of the emotional intelligence competence and is the ability of the leaders to know his own emotions, his own strengths and weaknesses, and level of confidence.

\subsection{Leadership in Nursing and among Nursing Students}

Generally speaking, leadership is vital in the healthcare sector for improvement of services and innovation of health system. According to Daly, Jackson, Mannix, Davidson, and Hutchinson (2014), developing clinical leadership skills among hospital nurses and other health professionals is of critical importance as they lead a wide range of hospital functions and influence the overall hospital performance. The Institute of Medicine (2010) has identified the need for allowing nurses to assume leadership roles at all levels from bedside to boardroom in order to participate with other health care providers to redesign the health care system. According to The Institute of Medicine (2010), what is needed is a style of leadership that involves interprofessional collaboration and respect.

Transformational leadership was suggested for nurses at all levels as an effective leadership strategy that enables followers to adopt the changes, follow an organizational vision, inspires them and creates a sense of commitment (Renjith, G. Renu, and George, 2015). One important finding of a study by Lin, MacLennan, Hunt, and Cox (2015) is that transformational leadership behaviours influence the quality of the working life of nurses and job satisfaction positively that due to leader support.

Regardless the organization needs for adaptive nurse leadership, Doody and Doody (2012) have concluded that such leadership has been restricted by hierarchy and bureaucracy, and because nursing has not promoted professional freedom. Dyess, Sherman, Pratt, and Chiang-Hanisko (2016) have identified gaps in communication and understanding between Generation $X$ nurse leaders and their Generation Y, also called the Millennials, staff. These gaps could 
prevent young nurses from taking a leadership role based on practices that are against their personal values and beliefs.

The Institute of Medicine (2010) proposed that nursing students should exercise their potential for leadership before graduation by participating in the university's leadership activities and discussing leadership issues with faculty. Olsen and Neale (2005) argued that clinical leadership training is needed at all levels, rather than limited to the senior clinical directors, to fill gaps in communications among teams, foster collaboration and maintain standards of clinical care. Also, they suggested introducing and continuing professional development programs throughout the training years.

Furthermore, one study that examined a leadership program in an undergraduate nursing course in Western Australia found that the leadership program was effective in improving leadership abilities and understanding of "self" of participants. Additionally, the leadership program improved the participant's problem-solving skills, critical thinking, planning, conflict management, negotiating skills and tolerance of others (Hendricks, Cope, and Harris, 2010).

Mathew (2014) found that graduating baccalaureate nursing students had lower transformational leadership skills compared to practicing nurses and RN-BSN students. Thus, Mathew (2014) concluded that improving the quality of clinical nursing education may improve nursing student's leadership skills and prepare them to become better nursing leaders in the future. In one case study, Ailey, Lamb, Friese, and Christopher (2015) provided lessons on how to develop the leadership capacity of a new generation of nurses effectively. To achieve this goal, they used the Model of Situated Learning in Nursing Leadership for generalist entry graduate nursing students at Rush University in Chicago that aimed to integrate course work with practice in teaching leadership. The outcome of the program was that students completed graduation final leadership projects aimed to improve the care of patients with intellectual and developmental disabilities. Those projects had presented at local and national conferences and webinars. On the other hand, Smith (2013) recommended simulation that varies from high fidelity simulation to pure role-play of leadership scenarios to and prepare nursing students to manage future clinical situations.

\section{The Conceptual Model of Study}

In the above literature review, many studies have provided evidence for the influence of the different leadership styles on the effectiveness and performance of leaders. Some leaders stick to one leadership styles in all situations and others adopt a leadership style that fit the situation.

In this study, based on the theory of generations and leadership theories, we explore the influence of the leadership styles of Generation Z Emirati nursing students on their competence. The model examine the effect of the most common leadership styles that are including transformational, transactional, 
autocratic, democratic, laissez- faire, and servant leadership styles on student's leadership skills, technical skills, performance, and confidence.

Additionally, a combination of more than one leadership style could be used by nursing students to achieve their most competence. See fig. 1 for the proposed conceptual model of the study

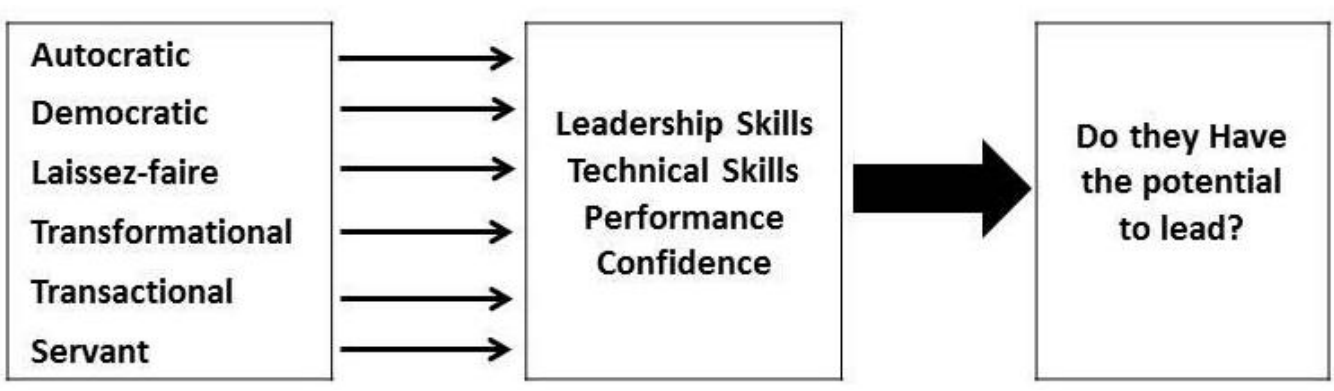

Figure 1: The Conceptual model of the study

\section{Purposes of the Study}

In this research, we will identify the leadership styles of Generation Z Emirati nursing students of Fatima College of Health Sciences (FCHS) specifically transformational, transactional, autocratic, democratic, laissez-faire, and servant leadership style. More, the authors will:

- Identify the impact of those styles on their technical skills (analytical skills).

- Identify the impact of those styles on their performance (effectiveness).

- Identify the impact of those styles on their confidence (self-awareness).

\section{The Significance of the Study}

In light of the literature review that carried out by authors, this study is the first that explore the leadership styles of the Generation $\mathrm{Z}$ (new generation) in UAE and the Arabic region. Also, it is one of the few types of research that target understanding the leadership styles of Generation $\mathrm{Z}$ nursing students worldwide. On the other hand, the authors will come out with recommendations to develop leadership styles of Generation Z nursing students and their competence based on the study results.

\section{Methodology}

\subsection{Study design}

This study will use a descriptive, quantitative methodology. A prepared survey will be used to collect the required data

\subsection{Data Collection Tool}

The survey contains 3 parts that are organized together to collect the required data. 
- The first part collects the required demographic data about respondents, which include location, age, gender, program length, and student's studying level

- The second part collects data about the participant's leadership practices. This part is built based on the Multifactor Leadership Questionnaire (MLQ) form 6S (Bass and Avolio, 2002), the five practices of extraordinary leaders (Kouzes \& Posner, 2012, pp. 14-25), leadership theory of Lewin, Lippitt, \& White (1939), and the servant leadership theory (Paterson, 2003).

In this part, the survey collects data about students' practices of modelling the way (idealized influence), inspiring a shared vision, challenging the process, enabling others to act, encouraging the heart, contingent reward, active management by exception (take corrective actions), autocratic (control), democratic (participation), laissez-faire (avoidance), and servant (humble, care and serve followers) leadership practices.

- The third part collects data about student's competence. It cover four competence components that are leadership skills including safe and trusting environment, empowers others, efficient Learning, nurture growth, and fosters a sense of connection and belonging (Giles, 2016), technical or analytical skills that are collect and analysis data, solve problems and make decision (Doyle, 2017), leadership effectiveness that includes selecting a leadership style that match the situation and possesses strong position power (fielder, 1964), and self-awareness that is the leader know his own strengths and weaknesses, and feel confident (Goleman, Boyatzis, and McKee, 2013).

For the second part, we used 5 points Likert scale included not at all, rarely, sometimes, often, and almost-always for each statement. While for the third part, we used 5 points Likert scale included strongly disagree, disagree, not sure, agree, and strongly agree.

\subsection{Population and Sampling}

Fatima College of Health Sciences is established to meet the UAE growing need for trained healthcare professionals. It offers bachelor degrees in pharmacy, physiotherapy, Radiography \& Medical Imaging, Health Emergency (Paramedics), and nursing at four different campuses of Fatima College of Health Sciences in Abu Dhabi city, Al Ain city, the Western region, and Ajman (Fatima College of Health Sciences, n.d.).

The authors collected data from a whole sample of the third and fourth year nursing students of Fatima College in April and May2019 via a printed paper survey for those who study in Al Ain Campus and online survey for those who are far in Abu Dhabi, Ajman, and Al Dhafra. The total number of respondents is 117.

\subsection{Inclusion and Exclusion Criteria}

The sample included the third and fourth year nursing students of Fatima College as those students spent a minimum of two years on study desk that 
boosted their leadership skills and competence compared to the first and second-year nursing students. The authors excluded the first and second-year nursing students and students from other health colleges.

\subsection{Ethical Consideration}

This study was reviewed and approved by the Fatima College of Health Sciences (FCHS) Ethical Committee. All participants were informed about the purpose of the study and given the choice to accept or refuse participation in the study.

The authors have adhered to ethical research standards all the study times, including limiting access to the data to authorized persons.

\subsection{Budget}

The authors covered the expenses of the study by themselves.

\section{Data analysis and Result}

IBM SPSS statistical software is used to conduct both descriptive and inferential data analysis to make a broader judgment on data.

\subsection{Background Information}

All the participants in this study were female nursing students and it comprises a total of 117 students. The majority of the respondents (85.5\%) were less than 25 years of age and the remaining 14.5\% were in the age group of 25-30 years. About two-fifths of the respondents reside in Al Ain followed by Ajman (30\%), Al Dhafra (19\%) and Abu Dhabi (11\%). Most (95\%) of our sample participants were attending 4 years nursing program and only 5\% were at 2 years Bridge program. Data in table 1 also indicates that $59 \%$ of the respondents were in 3rd year and $40 \%$ were in their 4 th year of study.

Table 1: Background information of the respondents

\begin{tabular}{|c|c|c|}
\hline & Number & Percentage \\
\hline Age Group & 100 & \\
19-24 years & 17 & 85.5 \\
$25-30$ years & 117 & \\
\hline Gender & & 100.0 \\
Female & 13 & \\
\hline Residence & 47 & 11.1 \\
Abu Dhabi & 35 & 40.2 \\
Al Ain & 22 & 29.9 \\
Ajman & & 18.8 \\
Al Dhafra & 6 & \\
Nursing Program Period & 111 & 5.1 \\
2 years (Bridging) & 1 & 94.9 \\
4 Years & 69 & 0.9 \\
\hline Study Year & 147 & 59.0 \\
$2^{\text {nd }}$ Year & 117 & 40.1 \\
3rd Year $^{\text {th } Y e a r ~}$ & & 100.0 \\
\hline
\end{tabular}




\subsection{Reliability Analysis}

The study instrument is a questionnaire that consists of three parts. First part collects personal information. The second part collects data about the participant's leadership practices, including transformational, transactional, autocratic, democratic, laissez-faire, and servant leadership styles, while the third part of the survey collects data about student's competence, including leadership, technical skills, effectiveness, and self-awareness. In order to assess the reliability of the data collection tool, the Cronbach's alpha was calculated and presented in table 2. The total Cronbach's alpha for the leadership styles variable is .934 and .963 for the student's competence variables. However the values of Cronbach's alpha for the variables under study should exceed 0.6 as it is the acceptable level of the reliability of the variables, three variables, i.e., the inspiring a shared vision, autocratic, and laissez- faire leadership has alpha values less than 0.6 .

Table2: Reliability Analysis

\begin{tabular}{|c|c|c|c|}
\hline & Variable & Cronb & Alpha \\
\hline \multirow{10}{*}{$\begin{array}{l}\text { Leadership } \\
\text { Behavior/Style }\end{array}$} & $\begin{array}{l}\text { Modeling the Way/ Idealized Influence } \\
\text { (Transformational) }\end{array}$ & .810 & \multirow{10}{*}{.934} \\
\hline & Inspiring a shared vision (Transformational) & .481 & \\
\hline & Challenging the process (Transformational) & .698 & \\
\hline & Enabling others to act (Transformational) & .711 & \\
\hline & Encouraging the Heart (Transformational) & .565 & \\
\hline & Transactional & .662 & \\
\hline & Autocratic leadership & .497 & \\
\hline & Democratic leadership & .501 & \\
\hline & Laissez- faire leadership & .401 & \\
\hline & Servant leadership & .674 & \\
\hline \multirow{4}{*}{ Competence } & Leadership Skills & .938 & \multirow{4}{*}{.963} \\
\hline & Technical Skills & .842 & \\
\hline & Performance & .713 & \\
\hline & Self-Awareness & .845 & \\
\hline
\end{tabular}

7.3Leadership Style and Behaviour

Predefined constructs from the previous research were used in this study using a five-point scale ranging from 1 (Not at all) to 5 (Almost Always). A total of 28 questions related to their leadership behaviour and style were asked to the respondents. These styles were transformational; transactional; autocratic; democratic; laissez-faire; and servant leadership styles. Analysis of data presented in Table 3 shows the results of descriptive statistics. 
Table 3a: Descriptive Statistics (Leadership Style and Behaviour)

\begin{tabular}{|c|c|c|c|}
\hline Leadership Style & Statement & Mean & S.D. \\
\hline \multirow{6}{*}{$\begin{array}{l}\text { Modeling the Way/ } \\
\text { Idealized Influence } \\
\text { (Transformational) }\end{array}$} & $\begin{array}{l}\text { I am effective in meeting course's objectives and } \\
\text { deadlines }\end{array}$ & 4.08 & 1.001 \\
\hline & $\begin{array}{l}\text { I maintain highest standards of honesty \& integrity by } \\
\text { avoiding academic dishonest activities such as } \\
\text { cheating, fabrication and plagiarism }\end{array}$ & 4.37 & .837 \\
\hline & $\begin{array}{l}\text { I attend my classes, video conferences, exams as } \\
\text { scheduled }\end{array}$ & 4.44 & .855 \\
\hline & $\begin{array}{l}\text { I communicate in proper manner (verbally and non- } \\
\text { verbally) with my class and faculty members }\end{array}$ & 4.31 & 1.021 \\
\hline & I am a role model for my class members & 3.64 & 1.244 \\
\hline & $\begin{array}{l}\text { I give my time and efforts to complete my } \\
\text { assignments and study projects }\end{array}$ & 4.16 & 1.000 \\
\hline \multirow{2}{*}{$\begin{array}{l}\text { Inspiring a shared } \\
\text { vision } \\
\text { (Transformational) }\end{array}$} & I am sure about a positive professional future & 4.44 & .933 \\
\hline & $\begin{array}{l}\text { I tell my class members about future professional and } \\
\text { academic success }\end{array}$ & 3.62 & 1.085 \\
\hline \multirow[t]{3}{*}{$\begin{array}{l}\text { Challenging the } \\
\text { process } \\
\text { (Transformational) }\end{array}$} & $\begin{array}{l}\text { I use the development opportunities to be a leader } \\
\text { (e.g., leading study group, representing my } \\
\text { colleagues, leading social and other activities } \\
\end{array}$ & 3.64 & 1.102 \\
\hline & $\begin{array}{l}\text { I develop myself by searching for innovative ideas } \\
\text { and projects }\end{array}$ & 4.08 & .882 \\
\hline & $\begin{array}{l}\text { I look for additional tasks and assignments to develop } \\
\text { and challenge my skills and abilities }\end{array}$ & 3.91 & 1.141 \\
\hline \multirow{2}{*}{$\begin{array}{l}\text { Enabling others } \\
\text { to act } \\
\text { (Transformational) }\end{array}$} & $\begin{array}{l}\text { I develop a strong sense of cohesion and team spirit } \\
\text { within my class members }\end{array}$ & 3.98 & 1.021 \\
\hline & I support other students to achieve study objectives & 4.17 & .976 \\
\hline \multirow{2}{*}{$\begin{array}{l}\text { Encouraging the } \\
\text { Heart } \\
\text { (Transformational) }\end{array}$} & $\begin{array}{l}\text { I encourage class members to get the highest benefits } \\
\text { of academic courses }\end{array}$ & 3.99 & 1.017 \\
\hline & $\begin{array}{l}\text { I congratulate my class members for their } \\
\text { achievements }\end{array}$ & 4.38 & .889 \\
\hline \multirow[t]{4}{*}{ Transactional } & \begin{tabular}{|l} 
I tell my class members to complete course \\
assignments to get the highest possible marks
\end{tabular} & 3.97 & 1.133 \\
\hline & $\begin{array}{l}\text { I tell my class members to complete course } \\
\text { assignments to avoid any possible cut in marks }\end{array}$ & 4.16 & .956 \\
\hline & $\begin{array}{l}\text { I put rules for my class members and I ask them to } \\
\text { stick to these rules }\end{array}$ & 3.03 & 1.562 \\
\hline & I get upset when my group members do mistakes & 3.36 & 1.365 \\
\hline \multirow{2}{*}{$\begin{array}{l}\text { Autocratic } \\
\text { leadership }\end{array}$} & I tell my class members what to do and how to do it & 3.55 & 1.249 \\
\hline & $\begin{array}{l}\text { I ignore my colleague's opinion when I make a } \\
\text { decision for them }\end{array}$ & 2.61 & 1.681 \\
\hline \multirow{2}{*}{$\begin{array}{l}\text { Democratic } \\
\text { leadership }\end{array}$} & I ask for my class members opinion on study projects & 3.95 & 1.082 \\
\hline & $\begin{array}{l}\text { I consider the opinion of my colleagues when I make } \\
\text { a decision for my group }\end{array}$ & 4.38 & .838 \\
\hline \multirow{2}{*}{$\begin{array}{l}\text { Laissez- faire } \\
\text { leadership }\end{array}$} & I let my class members decide whatever they want & 3.80 & 1.154 \\
\hline & $\begin{array}{l}\text { I only guide my class members when they do } \\
\text { something wrong }\end{array}$ & 3.52 & 1.315 \\
\hline \multirow[t]{3}{*}{ Servant leadership } & $\begin{array}{l}\text { I care about my class members when they face } \\
\text { challenges }\end{array}$ & 4.09 & .925 \\
\hline & $\begin{array}{l}\text { I sacrifice on some occasions to help my class } \\
\text { members }\end{array}$ & 3.62 & 1.187 \\
\hline & I am so humble when I deal with my class members & 4.14 & .999 \\
\hline
\end{tabular}


Table 3b: Descriptive Statistics (Leadership Style and Behaviour)

\begin{tabular}{|l|l|c|c|}
\hline \multicolumn{1}{|c|}{ Leadership Style } & \multicolumn{1}{|c|}{ Behaviour } & Mean & S.D. \\
\hline \multirow{5}{*}{ Transformational } & Idealized Influence & 4.17 & .723 \\
\cline { 2 - 4 } & Inspiring a shared vision & 4.04 & .8233 \\
\cline { 2 - 4 } & Challenging the process & 3.88 & .828 \\
\cline { 2 - 4 } & Enabling others to act & 4.088 & .881 \\
\cline { 2 - 4 } & Encouraging the Heart & 4.198 & .798 \\
\hline Transactional & Transactional & 3.638 & .903 \\
\hline Autocratic & Autocratic & 3.08 & 1.208 \\
\hline Democratic & Democratic & 4.16 & .790 \\
\hline Laissez-faire & Laissez-faire & 3.65 & .984 \\
\hline Servant & Servant & 3.95 & .811 \\
\hline
\end{tabular}

\subsection{Student's Competence}

In order to understand the impact of leadership style and behaviour on various skills a total of 18 questions were asked to the respondents. These questions include leadership skills; technical skills; performance; and self-awareness. Table 4 shows the results of descriptive statistics.

Table 4a: Descriptive Statistics (Student's Competence)

\begin{tabular}{|c|c|c|c|c|}
\hline Skills & Factors & $\begin{array}{l}\text { Statements } \\
\end{array}$ & Mean & S.D. \\
\hline \multirow[t]{11}{*}{$\begin{array}{l}\text { Leadership } \\
\text { Skills }\end{array}$} & \multirow[t]{2}{*}{$\begin{array}{l}\text { Safe and } \\
\text { Trusting } \\
\text { environment }\end{array}$} & $\begin{array}{l}\text { I am more able to apply ethical standards } \\
\text { such as fairness, and honesty in decision } \\
\text { making }\end{array}$ & 4.26 & .882 \\
\hline & & $\begin{array}{l}\text { I am more able to communicate my } \\
\text { expectation to my team and ensure all are } \\
\text { on the same page }\end{array}$ & 4.23 & .803 \\
\hline & \multirow[t]{2}{*}{$\begin{array}{l}\text { Empowers } \\
\text { others }\end{array}$} & $\begin{array}{l}\text { I am more able to teach, mentor, and } \\
\text { support my team }\end{array}$ & 4.15 & .934 \\
\hline & & $\begin{array}{l}\text { I am more able to share decision making } \\
\text { power with my group members }\end{array}$ & 4.20 & .902 \\
\hline & \multirow[t]{3}{*}{$\begin{array}{l}\text { Efficient } \\
\text { Learning }\end{array}$} & $\begin{array}{l}\text { I am more able to change my opinion } \\
\text { when I receive new information }\end{array}$ & 4.08 & .984 \\
\hline & & $\begin{array}{l}\text { I am more able to develop new ideas to do } \\
\text { the work }\end{array}$ & 4.21 & .915 \\
\hline & & $\begin{array}{l}\text { I am more able to support my team when } \\
\text { there is error or something wrong happen }\end{array}$ & 4.28 & .889 \\
\hline & \multirow[t]{2}{*}{$\begin{array}{l}\text { Nurture } \\
\text { Growth }\end{array}$} & $\begin{array}{l}\text { I am more willing to seek further } \\
\text { professional training and education in the } \\
\text { future }\end{array}$ & 4.24 & 1.056 \\
\hline & & $\begin{array}{l}\text { I am more able to practice self-awareness } \\
\text { (reflection) to correct my behaviors }\end{array}$ & 4.19 & 1.033 \\
\hline & \multirow{2}{*}{$\begin{array}{l}\text { Fosters a } \\
\text { sense of } \\
\text { connection } \\
\text { and belonging }\end{array}$} & $\begin{array}{l}\text { I am more effective in verbal and non- } \\
\text { verbal communication with my team }\end{array}$ & 4.27 & .906 \\
\hline & & $\begin{array}{l}\text { I am more able to demonstrate team } \\
\text { building skills }\end{array}$ & 4.18 & .906 \\
\hline \multirow{3}{*}{$\begin{array}{l}\text { Technical } \\
\text { Skills }\end{array}$} & \multirow{3}{*}{$\begin{array}{l}\text { Analytical } \\
\text { Skills }\end{array}$} & I am more able to search for information & 4.32 & .877 \\
\hline & & I am more able to solve problems & 4.20 & .912 \\
\hline & & $\begin{array}{l}\text { I am more able to articulate the knowledge } \\
\text { to organizational decision making }\end{array}$ & 4.03 & 1.021 \\
\hline
\end{tabular}




\begin{tabular}{|l|l|l|r|c|}
\hline Performance & $\begin{array}{l}\text { Effectiveness } \\
\text { Skills }\end{array}$ & $\begin{array}{l}\text { I am more able to apply analysis, planning, } \\
\text { implementation, and evaluation }\end{array}$ & 4.15 & .864 \\
\cline { 2 - 5 } & $\begin{array}{l}\text { I am more able to select the appropriate } \\
\text { approach to manage a specific situation }\end{array}$ & 4.16 & .851 \\
\hline $\begin{array}{l}\text { Self- } \\
\text { Awareness }\end{array}$ & $\begin{array}{l}\text { Knows own } \\
\text { strengths and } \\
\text { weaknesses }\end{array}$ & $\begin{array}{l}\text { I know better my strengths and } \\
\text { weaknesses }\end{array}$ & 4.32 & .918 \\
\cline { 2 - 5 } & Confidence & $\begin{array}{l}\text { I am confident that I can make the } \\
\text { difference }\end{array}$ & 4.31 & .978 \\
\hline
\end{tabular}

Table 4b: Descriptive Statistics (Student's Competence)

\begin{tabular}{|l|c|c|}
\hline Skills & Mean & S.D. \\
\hline Leadership Skills & 4.21 & 0.732 \\
\hline Technical Skills & 4.18 & 0.818 \\
\hline Performance & 4.15 & 0.756 \\
\hline Self-awareness & 4.32 & 0.882 \\
\hline
\end{tabular}

\subsection{Correlation Analysis}

Correlation analysis is conducted to measure the closeness of the relationship between two or more variables, where leadership styles are tested to check their significance and impact on nursing students' competence.

Table 5 presents the correlation analysis between various leadership behaviours and skills. As can be seen from the table, all the leadership behaviours and styles were highly correlated with skills at various degrees except the correlation between autocratic and self-awareness. All variables are tested at the 0.01 level of significance.

\section{Discussion and Conclusion}

The sample of this study shows that nearly most of the students of the 4 branches of Fatima College of Health Sciences were presented well in the study. $\mathrm{Al}$ Ain and Ajman campuses show the highest percentage of participation, as they indeed contain the highest number of students. Also, all participants are Emirati females, which go in with the actual fact on the ground. On other side, the sample included 17 participants $(=14.5 \%)$ who are above 24 years old, which is justified by the truth that generations could be overlapped and the categories of ages are not decisive among generations.

With respect to the descriptive statistics of the leadership style and behaviour, the standard deviation for all questions range from 0.837 to 1.562 . Hence, it reflects an accepted amount of variation in the sample, which is normal as the responses vary from one participant to another. Furthermore, the mean's analysis shows that the transformational leadership components, including encouraging the heart, idealized Influence, enabling others to act, and inspiring a shared vision having, respectively, the highest means in comparison to the other leadership styles, except the democratic leadership styles (4.19) and the servant leadership (3.95) that, also, considered high. Whilst the laissez-faire leadership (3.65), transactional (3.638), and autocratic leadership styles (3.08) having, respectively, lower means. Accordingly, we can say that the emirati nursing students practice favourable leadership styles such as the 
transformational and democratic leadership styles more frequently than the laissez-faire, transactional leadership, and the autocratic leadership styles.

On the other hand, the descriptive statistics of the student's competence, the standard deviation for all questions range from 0.803 to 1.056. Therefore, it, also, reflects an accepted amount of variation in the sample. Furthermore, the mean's analysis shows that all components of the student's competence, i.e., the leadership skills, technical skills, performance, and self-awareness are high and nearly all are at the same level.

A close look of the table reveals that idealized influence is highly correlated with the leadership skills (.745), performance (.702), technical skills (.672) and selfawareness (.653) whereas inspiring a shared vision; challenging the process; enabling others to act; and encouraging the heart are correlated with skills, but relatively lower as compared to the idealized influence. The correlation between the transactional style and skills shows that performance (.527) is highly correlated as compared to technical skills (495); leadership skills (.493); and selfawareness (.397). Autocratic behaviour is found to be least correlated with all the skills and there is no significant correlation between autocratic behaviour and self-awareness (.121). Democratic behaviour is also highly correlated with leadership skills; technical skills; performance; and self-awareness. The laissezfaire and servant leadership style were found to be highly correlated with all the competence skills.

In conclusion, the result of the study has provided an evidence for the favourable leadership practices of the generation $\mathrm{Z}$ Emirati nursing students; the students practice transformational, democratic, and servant leadership more frequently than the laissez-faire, transactional leadership, and the autocratic leadership. These leadership styles were also generally found highly correlated to student's competence. Therefore, the result of the study provides significant evidence respecting the leadership capability of the generation $\mathrm{Z}$ Emirati nursing students to lead in the immediate future. 
0
0
0
0
0
0
0
3
0
0
0
0
0
0
$\vdots$
07
0
0
0
0
0
0
0
0
0
0
0
0
0
0
0
0

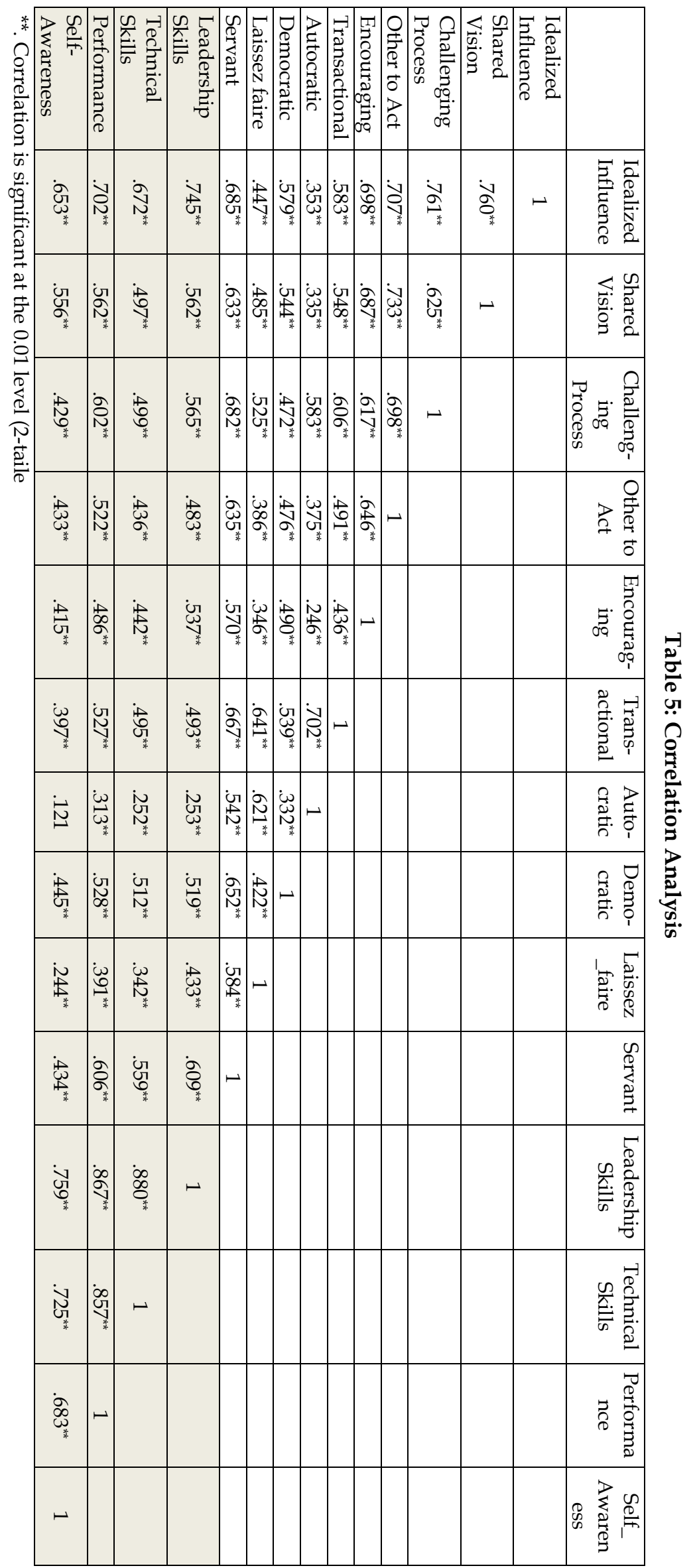




\section{Recommendation}

The authors of the paper believe that this study increases the awareness of the nursing education institutes about the practicality of understanding the generation gaps that could exist between generation $Z$ and the preceding generations, such as generation $X$ and $Y$. Thus, the generation $Z$ Emirati nursing students could be invited to take an active role in the education process. The gap between students and lecturers should not be considered as right or wrong, but it is just a difference.

On the other hand, the nursing managers in the UAE health organization should prepare themselves to receive those nurses in their organizations. We suggest them to provide generation Z Emirati nurses with a continuous well-prepared leadership and development program based on understanding the needs and leadership styles of those nurses. This understanding and support could keep generation $\mathrm{Z}$ nurses motivated, improve their professional competence, and enable the full potential in them.

Finally, we encourage scholars to consider longitudinal studies to explore the leadership styles of generation $\mathrm{Z}$ nurses and their impact on their competence in the work places.

\section{Limitations}

One limitation of this study is that some components of the data collection tool were found to have low reliability. Those items are the inspiring a shared vision, autocratic, and laissez- faire leadership styles. Therefore, future research should overcome this limitation by adding more questions to the survey that are relevant to those variables.

Another limitation is that the student's competence was measured by surveying students' feedback. This could be a source of bias that may affect the result of the study. Future research may consider surveying the feedback of the lecturers regarding students' leadership practices or reviewing the academic scores of the students as an evidence of their competence.

Finally, the population of the study is restricted to the nursing students of Fatima College of Health Sciences (FCHC). Researchers could survey students from other nursing institutes.

\section{Acknowledgment}

The authors would like to extend their gratitude and appreciation for the administrators and lecturers of the faculty of nursing of Fatima College of Health Sciences (FCHS) for the support and for all nursing students for participation in the study. 


\section{References}

Ahn, M. J., \& Ettner, L. W. (2014). Are leadership values different across generations? A comparative leadership analysis of CEOs v. MBAs. Journal of Management Development, 33(10), 977-990. https:// doi.org/10.1108/JMD-10-2012-0131

Ailey, S., Lamb, K., Friese, T., \& Christopher, B. A. (2015). Educating nursing students in clinical leadership. Nursing management, 21(9), 23-28.

Bass, B. (1990). From Transactional to Transformational Leadership: Learning to Share the Vision. Organizational Dynamics, 18(3), 19-31. https://doi.org/10.1016/00902616(90)90061-S

Avolio, B. J., \& Bass, B. M. (2002). Developing potential across a full range of leadership. Mahwah, NJ: Lawrence Erlbaum Associates.

Blanchard, K., \& Hersey, P. (1969). Life cycle theory of leadership. Training and development journal, 23(5), 26-34.

Bouvard, J. (2013). Not all MBA students can be leaders. Financial Times. Retrieved from https://www.ft.com/content/a1617430-c7ac-11e2-9c52-00144feab7de

Buckley, P., Viechnicki, P., \& Barua, A. (2015). A new understanding of Millennials: Generational differences reexamined. Retrieved from https://dupress.deloitte.com/dup-us-en/economy/issues-by-thenumbers/understanding-millennials-generational-differences.html

Carlyle, T. (1840). On Heroes, Hero-Worship, and the Heroic in History (Sorensen D. \& Kinser B., Eds.). New Haven; London: Yale University Press.

Chua, J., Abdul Basit, \& Hassan, Z. (2018). Leadership styles and its impact on employee performance. International Journal of Accounting \& Business Management, 6(1), 8094. doi:10.24924/ijabm/2018.04/v6.iss1.80.94

Dalluay, V. S., \& Jalagat, R. C. (2016). Impacts of Leadership Style Effectiveness of Managers and Department Heads to Employees' Job Satisfaction and Performance on Selected Small-Scale Businesses in Cavite. Philippines. International Journal of Recent Advances in Organizational Behaviour and Decision Sciences (IJRAOB), 2(2), 734-751

Daly, J., Jackson, D., Mannix, J., Davidson, P. M., \& Hutchinson, M. (2014). The importance of clinical leadership in the hospital setting. Journal of Healthcare Leadership, 6, 75-83. http://dx.doi.org/10.2147/JHL.S46161

Doody, O., \& Doody, C. M. (2012). Transformational leadership in nursing practice. British journal of nursing, 21(20), 1212-1218. https://doi.org/10.12968/bjon.2012.21.20.1212

Doyle, A. (2017). Analytical skills list and examples. Retrieved from https:// www.thebalance.com/analytical-skills-list-2063729

Dyczkowska, J., \& Dyczkowski, T. (2018). Democratic or Autocratic Leadership Style? Participative Management and its Links to rewarding Strategies and Job Satisfaction in SMEs. Athens Journal of Business and Economics, 4(2), 193-218. doi:10.30958/ajbe.4.2.5

Dyess, S., Sherman, R., Pratt, B., \& Chiang-Hanisko, L. (2016). Growing Nurse Leaders: Their Perspectives on Nursing Leadership and Today's Practice Environment. The online journal of issues in Nursing (OJIN), 21 (1). https://doi.org/10.3912/OJIN.Vol21No01PPT04

El-Haddad, M. (2006). Nursing in the United Arab Emirates: an historical background. International Nursing Review, 53, 284-289. https://doi.org/10.1111/j.14667657.2006.00497.x

Fiedler, F. E. (1964). A contingency model of leadership, effectiveness, Advances in experimental social psychology. New York: Academic Press. 
Fairholm, M. R. (2001). The themes and theory of leadership: James MacGregor Burns and the Philosophy of Leadership. Retrieved August 15th, 2018 from https://www.researchgate.net/publication/283049025_Themes_and_Theories_ of_Leadership

Famous Quotes by Vince Lombardi (n.d.). Retrieved from http://www.vincelombardi.com/quotes.html

Fatima College of Health Sciences (n.d.). About FCHS. Retrieved from http://www.fchs.ac.ae/En/AboutUs/Pages/default.aspx

Felfe, J., \& Schyns, B. (2002).The relationship between employees' occupational selfefficacy and perceived transformational leadership-replication and extension of recent results. Current research in social psychology, 7(9), 137-162

Giles, S. (2016). The Most Important Leadership Competencies, According to Leaders around the World. Harvard Business Review. Retrieved from https://hbr.org/2016/03/the-most-important-leadership-competenciesaccording-to-leaders-around-the-world

Goleman, D., Boyatzis, R., \& McKee, A. (2001). Primal leadership: The hidden driver of great performance. Harvard business review. Retrieved from https://hbr.org/2001/12/ primal-leadership-the-hidden-driver-of-greatperformance

Hagel, J., Wong, J., Benko, C., \& Erickson, R. (2014). Global Human Capital Trends 2014: Engaging the 21st-century workforce, Deloitte University Press. Retrieved from http://sharingtribes.com/wp-content/uploads/2014/10/Deloitte-report.pdf

Hendricks, J. M., Cope, V. C., \& Harris, M. (2010). A leadership program in an undergraduate nursing course in Western Australia: Building leaders in our $\begin{array}{llll}\text { midst. Nurse } \quad \text { Education } & \text { 252-257. }\end{array}$ https://doi.org/10.1016/j.nedt.2009.12.007

Hill, W. (1969). A situational approach to leadership effectiveness, Journal of Applied Psychology, 53(6), 513-517.

Iarocci, J. (2015). Why are there so many leadership books? Retrieved from https:// serveleadnow.com/why-are-there-so-many-leadership-books/

Institute of Medicine (2010). The future of nursing: leading change, advancing health. Transforming Leadership. Washington, DC: The National Academies Press. https:// doi.org/10.17226/12956

Iorgulescu, M. C. (2016). Generation Z and its perception of work. Cross-Cultural Management Journal, 18(1), 47-54

Kaiser, R. B., \& DeVries, D.L. (2000). Leadership styles. In W.E. Craighead and C.B. Nemeroff (Eds.) The Corsini Encyclopedia of Psychology and Behavioral Science (3 ${ }^{\text {rd }}$ ed.). New York: Wiley \& Sons.

Kouzes, J., \& Posner, B. (2012). The Leadership Challenge: How to Make Extraordinary Things Happen ( $5^{\text {th }}$ ed.). Jossey-Bass: San Francisco, CA, USA.

Lewin, K., Lippitt, R., \& White, R. K. (1939). Patterns of aggressive behavior in experimentally created social climates. Journal of Social Psychology, 10, 271-299.

Lin, P. Y., MacLennan, S., Hunt, N., \& Cox, T. (2015). The influences of nursing transformational leadership style on the quality of nurses' working lives in Taiwan: a cross-sectional quantitative study. Biomed central (BMC) Nursing, 14. https:// doi.org/10.1186/s12912-015-0082-x

Mannheim, K. (1952). The Problem of Generations. In P. Kecskemeti (Ed.), Essays on the Sociology of Knowledge (pp. 276-322). London: Routledge and Kegan Paul.

Mathew, L. (2014). An examination of transformational leadership among graduating baccalaureate nursing students and practicing nurses. Open journal of nursing, 4, 737-742. http://dx.doi.org/10.4236/ojn.2014.411079 
McGregor, D. M. (1957). The human side of enterprise. Management review, 64(11), $22-28$.

Mind Tools (2016). The Blake Mouton Managerial Grid. Retrieved from https://www.mindtools.com/pages/article/newLDR_73.htm.

Khan, M. S., Khan, I., Qureshi, Q. A., Ismail, M. H., Rauf, H., Abdul L., \& Tahir, M. (2015). The Styles of Leadership: A Critical Review. Public Policy and Administration Research, 5(3), 87-92.

Nanjundeswaraswamy, T. S. \& Swamy, D. R. (2014). Leadership styles. Advances in Management, 7(2), 57-62.

Northeastern University $4^{\text {th }}$ Annual Innovation Poll (2014). Innovation Imperative: Portrait of Generation $Z$. Retrieved from https://www.fticonsulting.com/ / media/Files/usfiles/insights/reports/generationz.pdf

Olsen S., \& Neale G. (2005). Clinical leadership in the provision of hospital care. BMJ, 330(7502), 1219-1220. https:// doi.org/10.1136/bmj.330.7502.1219

Ozkana, M., \& Solmazb, B. (2015). The changing face of the employees- generation Z and their perceptions of work - a study applied to university students. Procedia Economics and Finance, 26, 476-483.

Patterson, K. (2003). Servant Leadership: A Theoretical Model. Retrieved from https://www.regent.edu/acad/global/publications/sl_proceedings/2003/patt erson_servant_leadership.pdf

Pew Research Center (2019). Generation Z Looks a Lot Like Millennials on Key Social and Political Issues. Retrieved from https://www.pewsocialtrends.org/wpcontent/uploads/sites/3/2019/01/Generations-full-report_FINAL_1.18.pdf

Posner, B. (2004). A leadership development instrument for students: updated. Journal of College Student Development, 45(4), 443-456. http://dx.doi.org/10.1353/csd.2004.0051

Renjith, V., G. R., \& George, A. (2015). Transformational leadership in nursing. International Journal of Scientific Research and Management Studies (IJSRMS), 2(2), 112-118.

Rooke, D., \& Torbert, W. R. (2005). Seven Transformations of Leadership. Retrieved from https://hbr.org/2005/04/seven-transformations-of-leadership

Rost, J. C. (1993). Leadership for the twenty-first century. Westport, Connecticut: Praeger.

Singh, A. P., \& Dangmei, J. (2016). Understanding the Generation Z: the future workforce. South-Asian Journal of Multidisciplinary Studies (SAJMS), 3(3), 1-5.

Smith, C. (2005). Servant leadership: The leadership theory of Robert K. Greenleaf. Retrieved from http://www.carolsmith.us/downloads/640greenleaf.pdf

Smith, S. B. (2013). Integrating simulation in a BSN leadership and management course. Journal of Nursing Education and Practice, 3(11). https://doi.org/10.5430/jnep.v3n11p121

Spears, L. C. (2010). Character and Servant Leadership: Ten Characteristics of Effective, Caring Leaders. The Journal of Virtues \& Leadership, 1(1), 25-30.

Spillane, J. P. (2005). Distributed leadership. The educational forum, 69(2), 143-150. https://doi.org/10.1080/00131720508984678

Treviño, L. K., Hartman, L. P., \& Brown, M. (2000). Moral person and moral manager: How executives develop a reputation for ethical leadership. California Management Review, 42(4), 128-142. https://doi.org/10.2307/41166057

Tulgan, B. (2013). Meet Generation Z: The second generation within the giant "Millennial" cohort.

Retrieved

from http://www.rainmakerthinking.com/assets/uploads/2013/10/Gen-ZWhitepaper.pdf 
Van Winkle, B., Allen, S., DeVore, D., \& Winston, W. (2014).The relationship between the servant leadership behaviors of immediate supervisors and followers' perceptions of being empowered in the context of small business. Journal of Leadership Education, 13(3), 70-82. https://doi.org/10.12806/V13/I3/RF5

Walumbwa, F. O., Avolio, B. J., Gardner, W. L., Wernsing, T. S., \& Peterson, S. J. (2008). Authentic Leadership: Development and Validation of a Theory-Based Measure. Journal of Management, 34(1), 89-126. https:/ / doi.org/10.1177/0149206307308913

Weber, M. (1968). The basis of legitimacy. In The theory of social and economic organization (5 $5^{\text {th }}$ print, pp. 324-329). New York: Free Press.

Weber, M. (1978). The types of legitimate domination. In Economy and Society (2nd ed., pp. 212 -216). Los Angeles, California: University of California Press. 